Influencing and Promoting Global Peace and Security

\title{
Horkon minghts
}

Quarterly Journal by Beyond the Horizon ISSG - Volume 3 Issue 3

\section{Perspective: Can We Repatriate the ISIS Children?}

Anne Speckhard, Molly Ellenberg

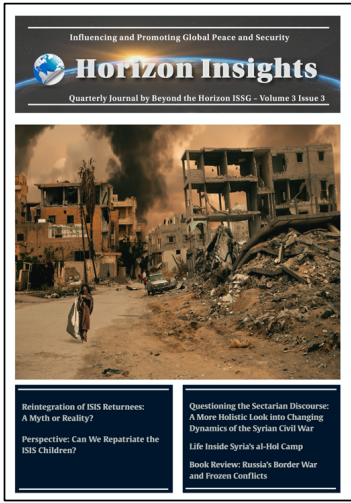

To cite this article:

Speckhard, A. \& Ellenberg, M. (2020). Perspective: Can We Repatriate the ISIS Children? Horizon Insights, 3(3), 17-35. https://doi.org/10.31175/hi.2020.03.02

For the link to this issue of the journal

https://behorizon.org/wp-content/uploads/2020/10/Horizon-Insights-2020-3.pdf

Horizon Insights Journal Homepage: https://behorizon.org/horizon-insights/

ISSN: 2593-3582 (printed), 2593-3590 (online)

Submit your article 


\section{Perspective: Can We Repatriate the ISIS Children? ${ }^{1}$}

Anne Speckhard ${ }^{2}$ and Molly Ellenberg ${ }^{3}$

Despite ISIS having been territorially defeated since 2019, the United Nations reported in January of 2020 that 8,000 children of foreign terrorist fighters [FTFs] remain in the custody of the Syrian Democratic Forces (SDF) with 700 to 750 of these children believed to be European. The same report noted that an additional 20,000 Iraqi children are currently being held prisoner in camps in SDF territory in northeast Syria and an unknown number of foreign teenage males are also held in SDF prisons.

ISIS children did not, at least initially, voluntarily join the ISIS Caliphate. They were either brought, or born, into the terrorist group by their parents who served ISIS in various capacities. Some teenagers also traveled to and joined ISIS of their own volition, but even these must be considered for repatriation in terms of their level of maturity and understanding at the time they undertook to do so.

When it comes to the very youngest among ISIS children, none of them can be considered dangerous in any way. They are infants, toddlers and preschoolers who are innocent and should not be held as prisoners on the basis of the crimes and guilt of their ISIS parents. While adolescents and teens pose an additional hazard as some older ISIS children were subject to ideological indoctrination, and some adolescents and teens were forced to become, or voluntarily became ISIS fighters. However, they were still minors and should be subject to a different legal standard as such. Leaving the children of ISIS to languish in camps throughout northeast Syria in dangerous situations facing disease, harsh conditions, Turkish incursions and bombardments, and ISIS enforcers and now the threat of COVID-19 is to risk them becoming a future generation of ideologically indoctrinated militants. To fail to put the health and welfare of these children first is also against international norms and laws of Western democracies which claim to follow standards of human rights.

While the UN urges countries to repatriate their ISIS children, there are numerous complications involved, one being that many of the ISIS wives have children from multiple fathers, meaning their children could claim various citizenships that their mother may not herself hold. Likewise, taking the children home either requires separating them from their mothers with whom they are housed (and also from their imprisoned fathers if they are still alive), something that is often looked upon as not in the best interest of the children and that may also open a legal doorway for adult ISIS members to later demand repatriation based upon a country's family reunification statutes. Many countries adamantly refuse repatriations of adult ISIS members fearing they will not be able to successfully prosecute them once returned due to unavailable and unreliable battlefield evidence, weak terrorism laws, and in the case of the women, having to prove involvement in supporting a terrorist group. Politicians also worry about the possible severe political consequences for government officials who choose to repatriate without being able to successfully prosecute due to strong public opinion against and fear over repatriations. Likewise, they worry that without being able to prosecute, country authorities may be unable to effectively protect the public from a battle-hardened returned terrorist mounting an attack on native soil. While this is a legitimate fear, it should also be noted that many adult ISIS members have returned already to Europe on their own before being captured in Syria.

The children of ISIS parents currently live in harsh and dangerous circumstances having already faced

\footnotetext{
1 This article was first published on 7 July 2020 on the Homeland Security Today, at https://www.hstoday.us/subject-matter-areas/counterterrorism/perspective-can-we-repatriate-the-isis-children/\#_ednref15

2 Anne Speckhard, Ph.D., is Director of the International Center for the Study of Violent Extremism (ICSVE) and serves as an Adjunct Associate Professor of Psychiatry at Georgetown University School of Medicine. She has interviewed over 700 terrorists, their family members and supporters in various parts of the world including in Western Europe, the Balkans, Central Asia, the Former Soviet Union and the Middle East. In the past three years, she has interviewed ISIS $(n=239)$ defectors, returnees and prisoners as well as al Shabaab cadres $(n=16)$ and their family members ( $n=25)$ as well as ideologues $(n=2)$, studying their trajectories into and out of terrorism, their experiences inside ISIS (and al Shabaab), as well as developing the Breaking the ISIS Brand Counter Narrative Project materials from these interviews which includes over 175 short counter narrative videos of terrorists denouncing their groups as un-Islamic, corrupt and brutal which have been used in over 125 Facebook campaigns globally.

3 Molly Ellenberg is a Research Fellow at ICSVE. She holds an M.A. in Forensic Psychology from The George Washington University and a B.S. in Psychology with a Specialization in Clinical Psychology from UC San Diego.
} 
Turkish and Turkish-based rebels bombardments on prisons and camps alike, with continued threats of further violent incursions into the region. Disease, violence and difficult conditions are a daily reality for these children who should be offered the protection of the countries they either came from or from which they have a right to claim citizenship.

This article examines the complications, challenges, barriers, failures and success stories relating to the repatriation of ISIS children currently living in northeastern Syrian camps. It also discusses the factors contributing to countries' decisions regarding their repatriation as well as advises on prudent steps to take following repatriation of this extremely vulnerable and at-risk population. ${ }^{4}$

\section{Who and Where are the ISIS Children in SDF Territory?}

The foreign children of ISIS fall between the ages of infants up to 18 years old and thus display a wide range in terms of potential repatriation risks. While infants, toddlers and preschoolers cannot under any conceivable rubric be considered dangerous, it is well known that children from the age of 6 and up were kidnapped, forced, lured, and placed by their parents in ISIS Cubs of the Caliphate training camps. There, the youngest children were trained to spy for ISIS, to preach ISIS's distorted version of Islam and to execute suicide missions in vehicles and by carrying bomb-filled backpacks to enemy checkpoints. Older children were weapons trained, forced to behead and otherwise execute ISIS prisoners, sent to perform guard duty (i.e. ribat), to fight battles and were also enrolled to become suicide terrorists. While the numbers of ISIS teens currently imprisoned (rather than housed in camps with their mothers) in SDF territory are not publicly available, these are likely the children of ISIS who were trained in weapons and who engaged as ISIS fighters and guards. Given ISIS's proclivity to indoctrinate, train and use children for violent actions, it is likely most useful to categorize ISIS children as those old enough to have really taken on the ISIS ideology and be weapons trained to an extent that they could be truly dangerous versus those who are too young to truly understand how to operate a weapon, or what an enemy of ISIS is, among other basic ideological tenets. Divided in this manner, one might see children up to age 11 as unlikely to be dangerous-and this goes without question for those under age five or six-whereas children from ages 12 to 18 may be so brainwashed and weapons trained as to be truly dangerous.

Likewise, a third category of ISIS children emerges based on the parents' lack of involvement in the group. ISIS rounded up and kidnapped children, separating them from their parents and forced them into the Cubs of the Caliphate camps. The most victimized group in this category are the Yazidi boys who faced ISIS onslaughts in which they were gathered and held with their family members at gunpoint and told to raise their arms. The adult men and older boys who had armpit hair were taken away to be slaughtered by ISIS, the women were forced into sexual slavery and the younger boys were placed in the Cubs of the Caliphate camps. Of the 240 in-depth interviews that the first author has made of ISIS defectors, returnees and prisoners, many Syrian ISIS members told about their observations of how once the captured Yazidi boys had become totally indoctrinated by ISIS, they repudiated their faith, took on ISIS's warped version of Islam and became fierce fighters and frequently volunteered for suicide missions. Given these boys had witnessed extensive traumas and were totally separated from anyone who loved them, it is not surprising they would long to exit this life and cling to promises made by ISIS trainers of Paradise in the hereafter. Similarly, it is not uncommon for kidnapped children to become completely aligned with their abductors as a means of psychological survival, displaying a serious form of Stockholm syndrome. Unfortunately, these Yazidi boys, who are among the most victimized ISIS children, may be, due to their deep psychic pain, isolation from family members, and heavy indoctrination and weapons training, the most dangerous among all of the ISIS children. Nadia Murad, the Yazidi Nobel Peace Prize winner, has spoken about how her own nephew was so indoctrinated by ISIS that when she is able to talk to him by phone while he still resides with ISIS. According to Murad, he insists he doesn't want to return and would murder her if he ever meets her

\footnotetext{
${ }^{4}$ Speckhard, A., \& Yayla, A. S. (2016). ISIS defectors: Inside stories of the terrorist caliphate. Advances Press, LLC.
} 
again. Similarly, many raped Yazidi women who were reunited with their heavily indoctrinated sons reported that they were very difficult to control, live with and reintegrate into society due to their aggressiveness, violence and continued repudiation of their Yazidi mothers as unbelievers and Satan worshippers. ${ }^{5}$

Within this third category of children are those born to Yazidi women raped by ISIS men. The children of mothers raped by ISIS members have been systematically rejected by the Yazidi community due to their parentage; the Yazidi religion does not allow for outside blood or mixed parentage and also responds to the Iraqi law officially labeling these children in a patrilineal manner as Muslim by rejecting them as non-Yazidi. Raped mothers are welcomed back to their Yazidi community but forced to make the painful choice to leave their children in orphanages in order to return home. As a result, some Yazidi mothers have opted to stay in Camp al Hol, not making their Yazidi identity and victimhood known, and mixing themselves with the ISIS women in order to keep their children. Others have placed their children in orphanages in Syria and Iraq and returned home. While repatriation for Yazidi children would normally mean returning them to their villages and homes, mostly in Iraq, the Iraqi current policy of classifying them as Muslim based on their father's religion and the Yazidi group's rejection of them makes their repatriation dilemma one of finding third countries to take them in, either as ISIS orphans, or with their mothers who chose to remain with their children rather than repatriate without them.

At present, FTF adult and teenage males are held in SDF prisons, while ISIS wives and Yazidi rape victims (who have not made themselves known to the authorities) are detained with their ISIS children in so-called refugee camps in northeast Syria. While the camps housing ISIS mothers and children are labeled for political purposes as refugee camps, there should be no mistake that they are prisons, as the women and children are not free to come and go, nor to receive visitors except with strict exceptions. The designation of refugee camp, versus prison, is made in order to make it possible for international nongovernmental organizations to be able to support them. The three largest camps in operation in the Fall of 2019 holding ISIS women and their children were Camps Ain Issa, al-Hol and Roj.

Camp Hol: The largest of these detainment camps is Camp al-Hol, which according to a UN Report dated April 2019, housed an estimated 75, 000 women and children. ICSVE data suggested at that time that at least 60, 000 of these were Syrians and Iraqis, many of which have since been released back to their tribes and families in Syria, or repatriated to Iraq. In the Fall of 2019, ICSVE was aware that at least a total 8,000 children and 4,000 wives of FTFs were held in the camp which roughly matches the January 2020 UN figures reporting a total of 8,000 foreign ISIS children detainees in SDF territory.

Camp Roj: By the end of 2018, it was reported that Camp Roj held a total of 2,000 women and children, with at least 500 women and 1,200 children based on our personal accounts in late November 2018. That number shrunk to 1,500 , as some governments facilitated repatriation of foreign women and children to their respective countries, although Camp Roj continues to receive transfers from al Hol and is also undergoing the building of a new wing onto the camp. In Fall of 2019, ICSVE estimated that Camp Roj housed upwards of 1,500 women and children of FTFs. While the exact numbers of foreigners (both women and children) in Camp Roj remain unavailable, based on our personal accounts as well as some reported in the media, it appears that over 50 percent of the total population in Camp Roj are wives and children of FTFs.

Camp Ain Issa: In Fall of 2019 Camp Ain Issa housed a total of 12,000 women and children. Based on ICSVE primary sources on the ground at that time, a total of 1,000 children and 265 women were foreigners (FTF families). Camp Ain Issa was bombarded during the Turkish incursion resulting in over 200 ISIS women and children escaping the camp. Some of these made their way to Turkish held territory to try to reach their consulates and be repatriated, but others disappeared. Since the destruction of Camp Ain Issa during the Turkish attacks, those women and children who were held or recaptured from the camp were transferred to other camps in the region. 
It is difficult to determine the exact numbers of women and children in the camps as the situation is constantly changing. Some countries have aggressively begun repatriations while most Western European countries staunchly refuse to repatriate. Russia, Kosovo, Kazakhstan and Macedonia, to name a few, have repatriated both ISIS women and children, sometimes up to 100 at a time, and Sweden, France and Germany have repatriated ISIS orphans, and Belgium has tried to do so as well.

The numbers in Camp Hol also change as ISIS women and children manage to smuggle out of the camp on a weekly basis-some to make it into Turkey and back to their home countries, others to disappear without trace. Germany, Ireland, and Finland have each accepted the rare repatriation of women and children who escaped from Camp Ain Issa and Camp al Hol and then made it to Turkey and requested to come home. Belgium appears about to accept some from this category as well.

As the situation is extremely fluid, and public figures are not always available, the exact numbers of ISIS children currently being held in SDF territory are hard to verify. The January 2020 UN report is likely the most reliable, reporting that 8,000 children of FTFs are currently imprisoned in northeast Syria, with 700 to 750 of these children believed to be European, meaning that these children either entered Syria as EU citizens or were born in Iraq or Syria to at least one EU citizen parent and are therefore EU passport eligible. Other sources corroborate the UN figures. For instance, the New York Times reports that there are approximately 900 children from Western countries, including from the European Union as well as Canada and Australia, in the camps as of May 2020. The Center for Global Policy estimates that there are as many as 750 children who are EU citizens or were born in Iraq or Syria to at least one EU citizen parent. Save the Children also recently reported that around 7,000 of those held in Camps al-Hol and Roj are foreign children, half of whom are under the age of five, meaning that they were likely born into the ISIS Caliphate rather than were brought there by their parents. According to Tanya Mehra and the International Centre for Counter-Terrorism - The Hague, 75 percent of the foreign ISIS children in Syria and Iraq were born in the conflict zone and are under the age of seven. ISIS orphans are held by friends of their parents in the camps or have been placed in orphanages. While there are no official numbers available, Human Rights Watch reported in 2019 that there were "hundreds" of orphans among the foreign children in these Syrian camps. Many Western countries have repatriated ISIS orphans of whom they are aware, as there are no complications about potentially opening a pathway for their parents to be repatriated as well.

While Iraq continues to accept transfers of their citizens from Camp Hol, the United Nations January 2020 report stated that 20,000 Iraqi children are still being in the northeast Syrian camps. Likewise, an unknown number of teenage males are also being held in the SDF prisons, with some undergoing rehabilitation in newly created centers. The nationalities and numbers of teenage males currently held in SDF prisons is not publicly reported and thus unknown.

The exact numbers of ISIS children born to Yazidi women as a result of mass rapes is unknown. In June of 2019, NPR's Jane Arraf reported that one orphanage in northeastern Syria housed 41 such children, but also stated that the Yazidi group's official estimates of children born to raped Yazidi women could be more than 1,000. Yazidi women also relinquished their children born of rape to orphanages in Mosul, Iraq. The authors are aware of several Yazidi women who hide with their children among ISIS women in camp Hol. How many there are in this category is also unknown.

When it comes to nationalities, Camp Hol and Camp Roj hold women and children from about 60 countries. In addition to a number of Westerners whom the first author was able to interview during the last years in all three camps (that is including Camp Ain Issa), which included women from Belgium, the Netherlands, Ireland, the United States, Germany, and France, the foreigner pool also comprises women from Russia, Indonesia, Malaysia, Morocco, Turkey, Algeria, Tunisia, Bosnia, Kosovo, Macedonia, Maldives, Morocco, and Uzbekistan, among others. It is estimated that Camp Roj alone hosts women from 40 countries. All of the aforementioned ethnic backgrounds and nationalities are scattered across the camps, with some of the high-profile Westerners such as American-born Hoda Muthana and British-born Shamima Begum having been moved to Camp Roj for their safety. FTF males held under the custody of the SDF in prisons are often the fathers of many of these ISIS children. They 
are also from about 60 countries. In northeast Syria, the first author has interviewed FTF males who are nationals of the United States, Canada, Australia, Trinidad and Tobago, the UK, Belgium, France, the Netherlands, Pakistan, Dagestan, Turkey, Denmark, Russia, Kosovo, Montenegro, Albania, Bosnia, Indonesia, Tunisia, Saudi Arabia, Morocco, Libya, Switzerland, Egypt, Luxembourg, and Germany. Many express deep concerns for the welfare of their wives and children and most have little to no contact with them.

\section{Conditions Faced by ISIS Children}

After Turkey's Fall 2019 onslaught in northeast Syria and the Trump administration's withdrawal of American troops supporting the SDF, the situation of ISIS detainees has become even more dire with severe overcrowding in all of the camps and prisons, COVID-19 becoming an impending threat, the possibility of further Turkish incursions and the possibility of Assad gaining control of the ISIS prisoners.

Currently, ISIS women and children reside in United Nations High Commission for Refugees [UNHCR]provided tents in these detention camps. The tents are hot in the summer, freezing cold during winter, and leak cold rainwater year-round. ISIS children face dusty air contaminated by pollutants from nearby oil fields; conditions that cause some to have chronic bronchial infections and to suffer from asthma. One Belgian mother told the first author that her child frequently struggled to breathe, with his lips turning blue and passing out at times. She was so worried for her child that she agreed he could be repatriated without her. Hoda Muthana's young son also suffers from chronic bronchial infection, has to be elevated at night in order to breathe, and appeared weak and lethargic with a deep wet cough when his mother was interviewed by the first author. All the mothers state that medications and doctor visits are hard to come by and that they struggle to keep their children healthy without good medication, diet and care. ISIS children and their mothers have died of Typhus as well as other diseases, malnutrition and they are now threatened by the specter of COVID-19.

Detainees have also died in tent fires, stabbings and other dangers in the camps. Medical care is poor and while over the past few years vaccinations have been offered, many mothers don't trust them and refrain from having their children vaccinated. They complain that the provided food lacks nutritious fruits and vegetables. While some ISIS women receive money from relatives back home via a prisonrun hawala system, and also through other illicit channels, those who do not have money face only the provided diet of dry lentils, rice, spaghetti, cooking oil and little more. The Center for Global Policy reports that 371 children died in the SDF camps of malnutrition and other ailments in 2019, underlining the urgency of the situation. Schools are lacking as well. In addition to all of these dangers, ISIS orphans that remain in the camps have faced dire circumstances with no one formally in charge of them or responsible for their care and welfare.

While some of the ISIS men and women held in SDF territory had become disillusioned of ISIS before even landing in prison, or have since rejected ISIS, some remain highly committed and are extremely dangerous. All of the camps housing women have suffered from ISIS enforcers still dedicated to the group who require the other women to continue to cover themselves and who punish those who speak out against ISIS. ISIS women still highly committed to the group teach their children to throw rocks and otherwise attack those who have become disillusioned. Likewise, these women preach to both children and one another about ISIS's ideology, spreading news about the ISIS leaders' latest speeches and claiming that the ISIS men will soon come to break them out of the camps and that the Caliphate will be rebuilt. ISIS schoolbooks and teaching materials have been found in Camp al Hol. American born Hoda Muthana, UK born Shamima Begum, Canadian American Kimberly Pullman and Irish Lisa Smith, among others who had backed away from ISIS, have been transferred out of Camp al Hol to other camps because the threat to their safety was too high.

ISIS enforcers in the camps have attacked other women, set their tents on fire, stolen their possessions, attacked, bitten, beaten, stabbed and murdered other women, as well as attacked camp guards, 
creating a sense of chaos, constant danger and oppression in the camps. Because the women cook for themselves, they are all armed with kitchen knives at their constant disposal as well as fuel oil for their cooking stoves with which they start fires. In 2019 a male guard at Camp al Hol was stabbed in the back by an ISIS woman and numerous murders of inmates also occurred. Likewise, in the last year, a gunfight broke out in Camp al Hol and one woman was said to have gained possession of a pistol. In Camp Roj, these ISIS enforcers keep a "kill list" which lists the female defectors who they say will be killed when the ISIS men come to free them from the camps. Those women who have taken off their niqabs or no longer cover their hair, or otherwise speak out against ISIS, have told the first author that they are terrified of the ISIS enforcers as well as the thought that ISIS men could break the women out of the camps.

\section{Legal status of the ISIS Children}

ISIS children by most legal conventions cannot be charged, prosecuted or imprisoned for the crimes of their parents who are in many cases guilty of a manifold of crimes. That said, they are currently imprisoned with their ISIS mothers, or in the case of orphans, on their own. Both foreign men and women held in SDF territory are currently detained without any local charges, although some have been charged and even prosecuted in absentia in their home countries.

As far as the legal status of adults, the SDF has requested a series of solutions, the first of which was to request all foreign countries to repatriate their citizens and legal residents who left from their home soil. This is a stance that the current U.S. administration also supports. While criminals are generally charged, prosecuted and imprisoned in the countries in which they committed their crimes, ISIS prisoners held in northeast Syria represent a special circumstance. First, it should be considered that nearly all FTFs legally transited through or resided in Turkey before illegally entering Syria. Likewise, the central government of Syria lost control of vast areas of the country and still has not gained control. The area in which the SDF battled and took custody of their ISIS detainees is currently governed by the SDF and the Autonomous Administration of North and East Syria [AANES] independently of Assad's government, although there has been a recent rapprochement between the two. The SDF and AANES are not formally a part of the Syrian government and the SDF is considered a non-state actor. Likewise, it is further considered by Turkey as a terrorist group, indistinguishable from the Kurdistan Workers' Party [PKK], although the U.S. refers to the SDF as our trusted ally in the fight against ISIS. Many European countries also refuse to deal with the SDF due to its alleged and actual ties to the PKK. Thus, the ISIS detainees who are currently held in SDF territory for the most part entered Syria illegally and were arrested and are now detained by a non-state actor that does not have the legal framework to charge or prosecute them.

When most European and many other countries refused repatriation, the SDF began to insist on having an international tribunal held on SDF territory to try the detainees. However, the international bodies that would normally do so, the International Criminal Court in the Hague or the United Nations were unlikely to agree to do so based on many considerations. The most important among them is that SDF territory is controlled by a non-state actor and resides within Syria, meaning that holding an international tribunal on Syrian soil would necessarily also include addressing the war crimes of Assad's government and any attempt by the UN to do so would result in a Russian veto. The second barrier to an international tribunal is the cost of trying so many detainees, thousands of them, given that such courts are usually reserved for trying the leadership versus the entire rank and file of an offending group. Even when they limit their activities to trying the leadership, international tribunals are extremely expensive and also hard to conclude even over many years. Holding an international tribunal in Iraq to try the SDF's detainees might be a possibility if the Iraqi government was amenable to doing so, which they are not. However, the issue then becomes one of European democracies endorsing transferring SDF detainees to a government which uses the death penalty, routinely tortures, and has in the case of ISIS held trials based on membership versus evidence of actual criminality. 
The third proposal made by the SDF is to charge and prosecute the foreign ISIS detainees locally, either using local or hybrid courts with international assistance. This proposal fits the desires of many European countries who want their ISIS detainees to remain in Syria rather than be repatriated and tried at home, but it is fraught with legal considerations which are too lengthy to consider within the context of this article.

In the meantime, the foreign ISIS children are held based on their parents suspected, and yet in most cases unproven, criminal actions which is contrary to all international legal standards. Likewise, ISIS adolescents and those who have now become adults since traveling to ISIS, such as Shamima Begum (who traveled to ISIS at age 15 and has since had her UK citizenship stripped) are being held without local charges, although some may be charged or have even been prosecuted in absentia at home.

Anthony Dworkin of the European Council on Foreign Relations acknowledges the special legal status of minors who chose to join ISIS: "If they did [choose to join] when they were young, and were committed to it, even so, they weren't responsible as adults for their decisions." While ISIS children who did not choose to join, and especially those who can in no way be considered guilty of any crimes, require protection from their home countries, these young adults who joined ISIS as minors are also worthy of consideration for repatriation and rehabilitation, the same way young adults can be tried in juvenile court for crimes they committed as minors. It should be noted, however, that the first Additional Protocol to the Geneva Conventions does not consider children aged 15 to 18 to be child soldiers, and 17 -year-olds in the United States can enlist in the armed forces with parental consent. Therefore, older teens and those who are now adults do constitute a special category in terms of repatriation and for the level of resp onsibility they can be held to for their actions and crimes.

Thus, it can be said that general legal practice in most countries is to not hold children accountable for the crimes of their parents, meaning that they should not be left in prisons and camps when they could be living freely and safely. Moreover, even minors who have committed crimes such as those described previously have protections under the law given their age and developmental level. Even more protections apply to children who have committed crimes under extreme duress or coercion, such as child soldiers. In 1959, the United Nations adopted the Declaration of the Rights of the Child, and in 1989, the Convention on the Rights of the Child became the most swiftly and widely ratified international human rights treaty in history. The only three UN countries that have not ratified the treaty are Somalia, South Sudan, and the United States. The treaty requires states to place primary emphasis on the best interests of the child in all matters concerning children and to ensure the protection and care of the child. It grants every child the right to live and to develop healthily. The child also has the right to an identity, including a nationality, and should not be separated from their parents unless doing so is necessary for the best interests of the child. Furthermore, the treaty grants the child the right to freedom of expression, thought, conscience and religion. The child has the right to privacy and the right to access information from the mass media, among many other rights. Most importantly, perhaps, Article 39 of the Convention on the Rights of the Child holds that child victims of armed conflict have a right to physical and psychological recovery and social reintegration, and that such recovery should take place in an environment that fosters the child's "health, self-respect, and dignity." All of these rights firmly support the repatriation of ISIS children, even if doing so results in the child being separated from their parents, although the treaty would support repatriating mother and child together as the optimal option.

Regarding the right to a nationality, legal barriers exist in regard to establishing citizenship for children who often only have ISIS documents as birth certificates. In ISIS, women were pushed to marry and remarry extremely quickly and were forced to live in squalid guest houses (madhafas), when they were unmarried. After one husband was killed, women would often remarry even before the completion of their iddah, the period of time required in Islam to ensure that the women had not become pregnant by their previous husband. Therefore, many women in the SDF camps are widows with multiple children by multiple husbands. The different children of one mother may then have claims to citizenship in different countries. If the mother's country will not repatriate her children, or she is a local Syrian, they 
may then be separated not only from their mother but from their siblings as well.

of course, there is a possibility that children may not be granted citizenship at all. Children born under ISIS were granted birth certificates by the terrorist group, which the United Nations has urged countries to utilize in giving those children official documents. Establishing a child's identity can also be achieved through DNA testing. Using the results of those tests and ISIS birth certificates, officials can determine a child's true parents (or grandparents in the case of orphans) and therefore their right to citizenship. However, there is the added complication that countries have stripped some ISIS members of their citizenships. Hoda Muthana was born in the United States, for instance, and believed she was a U.S. citizen based on having two U.S. passports issued to her over her lifetime. However, her citizenship was denied by the Trump Administration based on the fact that her father who was no longer a diplomat was still considered in diplomatic status by the U.S. State Department when she was born, a fact that makes her ineligible for her U.S. citizenship claim. Her son was born in Syria before her citizenship was officially challenged, meaning that he also was thought to be eligible for a U.S. passport. However, the Administration claims that Ms. Muthana never actually had a right to American citizenship, suggesting that her son also does not have a right to American citizenship, despite the fact that his naturalized American grandparents are ready and able to take him in. Similarly, Shamima Begum's British citizenship was stripped in 2019, with the government claiming that she could become a Bangladeshi citizen through her father. Ms. Begum gave birth prior to her citizenship being stripped but the U.K. made clear that her son was nevertheless eligible to claim British citizenship. Still, the government did not repatriate him, and he died three weeks after his birth.

\section{Barriers to Repatriation}

The barriers to repatriating ISIS children are many. Foremost among them is the fear by many countries' authorities, particularly in those with weak terrorism laws, that opening the door to repatriate ISIS children will result in the return of their parents as well, many of whom may be unrepentant terrorists. This fear is particularly strong if the government is not confident that the returned ISIS adult has given up terrorism or can be successfully prosecuted. Moreover, many countries like France, for instance, face a serious prison radicalization problem, and thus fear that even with successful prosecutions these unrepentant ISIS returnees may seed themselves in the prisons. Europeans also generally give short sentences and would likely have some legal obligation to count time served while held in SDF territory, so the women in particular, even if successfully prosecuted, might be set free in a very short time. For those held longer, only some countries have good terrorist rehabilitation programs currently running in their prisons and none are 100 percent successful, nor do all terrorist prisoners agree to participate.

In Europe, repatriating ISIS children does seem to open the door for their parents to also demand repatriation as European laws allow for families to remain intact. Article 94 of the European constitution would allow an ISIS parent whose child was repatriated to directly appeal to Article 8 of the European Convention on Human Rights [ECHR], which refers to the right to family life. This means that if children of living ISIS members are repatriated, their parents would most likely be able to also demand repatriation based on human rights laws. This would apply for both ISIS men and women. As a result of such fears, most countries that have repatriated some children have chosen to repatriate only orphans, as doing so poses the fewest moral, legal, and political barriers.

There is also the moral and humanitarian issue of separating a child from his or her mother that stands as a barrier to repatriation if the country does not wish to repatriate both. Most psychologists and human development specialists would argue that to separate a child from his or her mother is not in the best interest of the child. Surely, repatriating both mother and child is ideal, but leaving a child in a highly dangerous environment, even if they are with their mother, also cannot be considered in the child's best interest. Thus, if there are legal and security concerns that preclude repatriating the mother, and she is to remain in the SDF camps, it can be argued that it is in the best interest of the child to be removed from her custody. To do so means that the child can have access to social support, 
education, healthcare, safety, psychological treatment and a non-radicalized personal network versus stay in danger in the camps.

In the case of repatriating a woman who will be prosecuted and imprisoned, it should be noted that in general with any imprisonment Western countries routinely separate weaned infants and older children from their mothers when the mother is incarcerated, although frequent visits are allowed, which would not be the case in repatriating children apart from their mothers and fathers left behind in Syria.

In most Western countries, it is also considered best practice for children to remain with their parents unless they are being abused or neglected. When a child is removed from a parent for abuse or neglect, the goal is for the child to eventually be reunified with their parents once authorities are confident that the child will be safe and protected. ISIS parents could conceivably have their parental rights temporarily or permanently severed given it is clearly an act of abuse or neglect for any parent to have knowingly taken their child into ISIS territory if that parent had a clear understanding of what ISIS stood for and the crimes it was committing. That an ISIS child would be separated from his or her mother on this basis is no different than separating any child from a mother who has committed others acts of abuse or neglect. For instance, children in the UK have been separated from parents who attempted to travel to ISIS with them but were apprehended before doing so.

Of course, this moral aspect of repatriation seeps into the legal sphere as well. If a mother refuses to allow her child to be repatriated without her, the case becomes more complicated. In the U.S., laws respect the rights of either parent to travel legally abroad with their children and to have custody over them while abroad. Thus when the first author tried to assist American Samantha el Hassani's sister to repatriate, at Samantha's request, two of her children to live with their aunt in the U.S., the U.S. State Department's stance was that without directly knowing Samantha's wishes they would not interfere and they claimed that they had no way to communicate with her. This posed an interesting conundrum as the first author argued that all four of Samantha's children should receive the full protection of the U.S. government, particularly the eldest two who were born in the U.S. and carried American passports. She argued that since the U.S. government sent their Navy SEALs to attempt to rescue journalist James Foley, who had voluntarily gone into ISIS territory, they should do the same to rescue Samantha's American children who had been taken into ISIS without their knowledge or consent. Moreover, these children were at the time of this discussion not even captives of ISIS, as Foley had been, but were residing in a camp run by our SDF allies with plenty of American soldiers about. While refusing to discuss her specific case due to privacy concerns, the U.S. State Department argued three points: That the children needed to be identified as Samantha's children with genetic testing, that there were no U.S. personnel that could venture into Syria to assist in that matter, despite the U.S. military presence and multiple bases located near the camp, and that Samantha had a right to privacy and to travel unimpeded with her children.

The first author argued that while the last point was normal in a divorce case, El Hassani's case was more akin to that of child abuse or neglect, as Ms. El Hassani had knowingly taken her children not just abroad, but into a war zone with the intent for her family to join and support a terrorist group. She argued that the federal government should have some mechanism for at least temporarily severing or suspending her parental rights so that they could act on behalf of the children to bring them to safety. When the U.S. Department of Justice became involved, they agreed with this argument. Ultimately all four children were repatriated along with their mother who is now imprisoned and facing terrorism charges.

Interestingly, the argument that it is too risky to send any foreign affairs personnel into northeast Syria to assist in repatriating ISIS children has been made not just by the U.S., but by many countries, and has thus served as a significant barrier to repatriation in many dire cases. The UK's Sajid Javid said that he would not risk sending any personnel to save the life of Shamima Begum's son, who was born while she was in Camp Roj. Despite the first author, and likely many others, having written letters warning of this likely inevitability, the child perished not long after he was born. While the argument of sending 
officials into danger is legitimate, it must also be balanced by the fact that U.S. and coalition troops are present in northeast Syria and that military escorts could likely be provided. To give an idea on the dangers, the first author has traveled repeatedly to all the camps without armored cars or bodyguards and has offered to help escort any children to be taken home to Western countries. Thus, this argument seems to be constructed because the countries using it do not in fact wish to repatriate.

Western country officials have also been frustrated by the logistics of trying to repatriate children. For instance, a Belgian official told the authors that he had requested a plane from the U.S. military to repatriate Belgian children, but his request was denied. A U.S. State Department representative later explained to the authors that this was based on the insistence of the U.S. government to not provide air transport for any ISIS children from northeast Syria without an ISIS adult also being present. This prerequisite appears to be the current administration's way of pressuring countries that wish to repatriate their ISIS children with U.S. assistance to also repatriate ISIS adults. It should be noted that the U.S. stance is that all countries need to repatriate all of their ISIS members from northeast Syria, parents and children alike. However, placing such a barrier to providing air transport for innocent children seems to fly in the face of humanitarian concerns for the children. Similarly, a Dutch lawyer working on behalf of ISIS mothers and children told the first author that he had come to an agreement with his country to take them back, but that the Dutch government insisted that he arrange for them to get to Erbil in Iraq in order to do so. As a private citizen, he could not arrange this with the SDF. Moreover, German officials have expressed concern to the first author that Iraqis have threatened to arrest any ISIS adults in Erbil whom the Germans might try to transit out of northeast Syria via Iraq. An Albanian CVE official also worked with ICSVE to try to repatriate a young girl brought by her father into ISIS but was told by the AANES that despite his position in the government, the request had to come from the foreign ministry, a stumbling block that the Albanian official could not overcome. Thus, many countries place unnecessary barriers to repatriation for their own political reasons and the SDF is also particular about who may make requests and who may be repatriated. Currently, the SDF's preference is to try the ISIS women in local courts versus have them sent home.

There is also the issue of identifying children. Some ISIS children whose parents were killed were taken in by ISIS women, as were the children of Yazidi mothers raped by ISIS men. The most reliable way to identify a child is through genetic testing, but if there is no trusted official to carry it out or the mother or father refuses to participate, the child may not be able to be identified scientifically, forcing countries to rely on ISIS-issued birth certificates or statements of witnesses.

Countries also claim that repatriating a child while leaving his or her mother in Syria would open the door to allow the mother to claim the right to return home, in the best interest of the child. In terms of child abuse and neglect cases, this would mean that the mother has promised to no longer abuse or neglect her child, in this case by removing herself from the dangerous environment. Thus, courts may consider allowing the mother to return home as being in the best interest of the child, despite fears surrounding the mother's level of radicalization and the justice ministry's ability to prosecute her.

Finally, political considerations color the debate regarding repatriations of children. Given that repatriating a child alone is more palatable to the public than repatriating a child with his or her mother, most repatriations that have occurred have been of orphans due to the aforementioned moral and legal barriers to separating a child from their mother, and father if he is living. Indeed, the political consequences of repatriation are many. In Finland, Minister of Foreign Affairs Pekka Haavisto was investigated for his push to repatriate Finnish women and children and his firing of a ministry director who opposed the efforts. The Finnish security services maintained that both women and children would pose national security risks should they be repatriated. In Norway, the governing coalition was disbanded following the repatriation of a woman and her two children from Syria. Even though the mother was arrested upon arrival in Norway, many thought the children should have been repatriated alone. Shamima Begum's case has been fraught with political indications. From the outset, Ms. Begum was judged far more harshly by the British public than women of European descent who also joined ISIS, with her photo even being used as a target at a shooting range. Her citizenship was stripped, and 
the UK government claimed that they were not willing to risk Britons' lives to repatriate her baby, who later died. Ms. Begum's family lawyer, the first author, and many others doubted the sincerity of this statement, volunteering to go to Syria themselves and claiming that it was not too dangerous to rescue a child. If governments were willing to send troops to save a journalist captured by ISIS, surely, they claimed, the government could send troops or officials into SDF camps to retrieve children. Shortly thereafter, the UK repatriated a group of orphaned children, indicating that they were willing to save those who did not garner such a harsh public reaction. This action contradicts previous statements regarding the safety of repatriating children, but there are many other policies that also impact whether a child can be retrieved from Syria.

\section{Country Policies Concerning Repatriation of ISIS Children}

The policies of countries in regard to repatriation are often inconsistent and applied differently when it comes to orphans versus children with living ISIS parents. The following is a brief recap on differing country policies:

Countries in Europe such as Germany and Norway have a policy of repatriating children and occasionally women on a case-by-case basis. Although this has resulted in successful repatriations, the piecemeal approach can be heavily swayed by public opinion. Belgium and the Netherlands, along with Australia, have stated that they will repatriate children only, once again favoring unaccompanied children; either orphans or children whose parents have voluntarily given up custody. Other European countries such as France have allowed FTFs, including women, to be prosecuted in Iraq, where they are likely to receive lengthy sentences. One French ISIS woman with a life sentence interviewed by the first author in Iraq was able to send her young children home from Iraqi prison to live with relatives in France. According to Anthony Dworkin, these European countries have posited that their policy of having FTFs be tried in the country in which they committed their crimes, either Iraq or Syria, as being one of principle. Dworkin argues that this is not so much a matter of principle, however, but one of externalization. France has also repatriated small numbers of orphaned and sickly children but leaving behind those same children's healthier siblings. Most recently, two French mothers gave up custody of their children so that the children could be repatriated along with a group of orphans. Other mothers refuse to give up custody, hesitant to trust a government they feel has abandoned them to care for their children. Tunisia and Trinidad and Tobago also repatriate only children. Morocco and most of the Balkan countries have repatriated many women and children as well as male FTFs. Many other countries, including Bulgaria, Singapore, Sweden, and Canada, will not facilitate return of FTFs or children, but will accept them back into the country if they are able to return on their own. Some ISIS women and their children escaped from Camp Ain Issa when it was bombed and others smuggled themselves out of Camp Hol, and once in Turkey were able to pressure their governments to repatriate them. Meanwhile, the United Kingdom, Denmark, Switzerland, Bahrain, Israel, and others have taken steps to revoke citizenship of FTFs, though their preferences regarding where the FTFs are tried (Syria or Iraq versus at home) differ from one another. ${ }^{6}$

Thus far, the most repatriations of children have been by the Russian Federation, Kosovo, Turkey, Uzbekistan, and Kazakhstan. The Russian Federation's repatriation program is led by Chechen leader Ramzan Kadyrov, and by Sevil Novruzova, a Dagestani woman running a rehabilitation and reintegration program, as most Russian FTFs were from the Russian republics of Chechnya and Dagestan. ${ }^{7}$ Considering that Kadyrov was sanctioned by the U.S. for violations of human rights, his persistence in repatriations of ISIS children and treating them as blameless is noteworthy, particularly since Russian adults who have joined ISIS often face brutal punishments. Kazakhstan has repatriated more than 400 children and 100 mothers, regarding all of the children as victims even if they have been radicalized. Kazakhstan has also implemented rehabilitation programs that are necessary to ensuring that the children are able to adjust into the society and not conduct violent attacks in the future. Under

\footnotetext{
6 HOFFMAN, A., \& FURLAN, M. (2020). CHALLENGES POSED BY RETURNING FOREIGN FIGHTERS.
}

7 Nicolson, D. (2017). Foreign Terrorist Fighters from the North Caucasus. Connections, 16(4), 69-88. 
the auspices of Kazakhstan's Ministry of Education, two non-governmental organizations have opened 17 rehabilitation and reintegration centers that employ mental health professionals, religious scholars, lawyers, healthcare professionals, and teachers, all of whom are committed to helping the children and their mothers. In Kosovo, deradicalization programs for returnees involve addressing the individual factors that contributed to the adults' decisions to join ISIS, as well as the structural inadequacies that made some Kosovars feel marginalized and desperate for opportunity - desperate enough to leave Kosovo to join ISIS. This societal aspect of deradicalization that involves listening to and addressing returnees' legitimate grievances is one with which many Western European countries have struggled.

In addition to the FTFs' home countries, the AANES and SDF itself also have a stake in the repatriation of children, as well as the FTFs. Initially, the SDF urged countries to repatriate their FTFs, but then moved to favor an international tribunal to try the ISIS members. One reason that initial efforts to promote repatriation failed is that the AANES is not a recognized state, so it does not have extradition treaties with other countries, provided those countries would be willing to work with a non-state at all. The proposed SDF tribunal is unlikely to be established as previously discussed, as Russia would veto the creation of a system that would likely prosecute its ally, the Syrian Assad regime, alongside ISIS. It is also noteworthy that an international tribunal for crimes committed in Iraq would also not likely be approved by European countries because Iraq uses the death penalty and Iraq itself would also have to agree to holding a tribunal on its soil. It is contradictory, however, that these same European countries have nevertheless allowed their own citizens to be tried in Iraqi courts that did not require European cooperation. Currently, the SDF and AANES have shifted to promote a hybrid system involving repatriations as well as using their own local courts and more permanent prison system. With regard to children, however, the SDF does not have adequate infrastructure to care for the children of FTFs who have been sentenced to prison and are no longer being housed in camps, nor does it have the infrastructure to provide more permanent housing for prisoners with long sentences. Therefore, the SDF requires support from other countries either by repatriating their FTFs and their families or by providing financial and military support to help the SDF maintain control. Furthermore, even if the AANES and SDF were to use the local court system, because it is not a recognized state, the FTFs' lawyers could argue that its legal system is invalid and that the FTFs must be brought to justice in a properly organized legal system, as is required by the United Nations Security Council Resolution 2396.

\section{What Have the ISIS Children Experienced and What Do They Need to Rehabilitate?}

Fully understanding the experiences of the ISIS children is a critical aspect of repatriating them and providing them with trauma-informed support services upon return. As stated above, many of the younger children were born into ISIS and have never known life outside of the Caliphate and the camps. Many are malnourished and have not had access to adequate healthcare, including vaccinations. In the Caliphate, the children likely witnessed corpses on the road, if not the executions themselves. Many ISIS members interviewed by the first author referenced children playing with the severed heads left in Naim Square in Raqqa, for instance. Given ISIS's propensity for cruel and brutal punishment, children may have seen their parents flogged, arrested or harassed or have been beaten and abused themselves. The American son of Samantha el Hassani was forced by her ISIS husband into threatening U.S. citizens on behalf of ISIS. When his mother tried to stop it from happening, she was badly beaten. In Camp AlHol, ISIS enforcers rule with an iron fist. Their children have been subject to indoctrination into the ISIS ideology, with one Instagram account run out of Al-Hol boasting that the still-radicalized women had taught their children to force people to raise their index finger, ISIS's symbol for tawheed, the oneness of God, when they passed through a makeshift checkpoint. The Instagram account claimed that the children were throwing rocks at anyone who refused to do so, thus perpetuating a cycle of violence and a belief system that espouses it. The children of mothers who have been disillusioned by ISIS may still be subject to indoctrination by the camp's more powerful women, and they may be traumatized by seeing their mothers harassed and even assaulted for disobeying the ISIS enforcers. They may also have 
been bullied themselves by the enforcers' children. Irish Lisa Smith said her infant child was almost killed by a rock thrown into their tent by an ISIS enforcer.

The children who were not born into ISIS, but rather taken there by their parents pose a different set of risks and considerations. Older ISIS children who were born in the West have already experienced life in a secular, democratic society, though they may have been too young to understand its values. Some have attended secular schools, and most have met and interacted with non-radicalized family members, friends, babysitters, and teachers. However, their age means that they have likely been exposed to even more of the ISIS ideology and violence than the younger children. At the peak of its Caliphate, ISIS operated schools that taught their interpretation of shariah, as well as weapons and other military training. Overall, the goal of ISIS schools was to normalize violence, including by providing parenting materials instructing mothers to teach their children to use violence toward their enemies. Children who attended these schools were imbued with ISIS's warped ideology and sense of morality during their formative years, when their brains were most subject to change. Some children may have even been Cubs of the Caliphate, ISIS's youngest fighters, who were often used as suicide bombers. An ISIS emir interviewed by the first author explained his criteria for determining who could fight with ISIS: "A fully-grown man has to have his semen. This is according to shariah." This definition of a wet dream indicating that a boy is ready to fight in battle or become a suicide bomber allowed ISIS to justify sending boys as young as 12 years old on fatal missions according to this emir. ${ }^{8}$ In actuality, even younger immature children were also sent on suicide missions and forced to behead and execute for ISIS.

Many interviewees told the first author about very young children being in the Cubs of the Caliphate camps and ISIS's own propaganda reveals the use of young children as executioners. ${ }^{9}$ One young ISIS member recalled to the first author that it took him over a year after escaping from ISIS into Turkey, at his parents' insistence, to overcome their deep ideological training. Likewise, the ISIS emir referenced earlier stated that ISIS children would cry and protest if they were moved back in the line to become suicide bombers and that they were as happy as children at holidays when their turn to suicide came. These children, therefore, may well have committed crimes as Cubs of the Caliphate, albeit without true awareness of the wrongness of their actions or the ability to say no to carrying them out. Many ISIS cubs told the first author they were forced to act on behalf of ISIS and failing to obey orders resulted in beatings and executions. One Iraqi cub told about being called to perform an execution and later throwing up and becoming addicted to alcohol in order to try to deal with his subsequent posttraumatic stress disorder [PTSD].

These children, like child soldiers of other conflicts, ought to be treated as victims, not perpetrators. In a study of ISIS child soldiers in Iraq, the child soldiers showed a significantly higher prevalence of PTSD, depressive disorders, anxiety disorders, and somatic disturbances than other Iraqi children. Their self-esteem was also significantly reduced. ${ }^{10}$ These psychological issues must be addressed during rehabilitation, as well as the stigma attached to having been a child soldier that may be detrimental to their reintegration. Even those who did not commit crimes but were used in ISIS propaganda will be identifiable to their communities as having been a part of the ISIS machine. Others may have been trained to preach ISIS's ideology in public areas. ${ }^{11}$

As with all deradicalization programs, there is a crucial point of reckoning in which older children realize the depravity of their crimes and must acknowledge their guilt in order to forgive themselves. ${ }^{12}$ Even if children were kept home from school by parents who understood the danger of exposing them to ISIS's ideology, they have now spent years in isolation and likely have delays not only in their academic learning, but in their psychosocial development that comes from interactions with same-age

\footnotetext{
8 Speckhard, A., \& Shajkovci, A. (2017). Confronting an ISIS Emir: ICSVE's Breaking the ISIS Brand Counter-Narrative Videos'. International Center for the Study of Violent Extremism (ICSVE), 29th May.

${ }^{9}$ Benotman, N., \& Malik, N. (2016). The Children of Islamic State. Quilliam Foundation, 7.

${ }^{10}$ Kizilhan, J. I., \& Noll-Hussong, M. (2018). Post-traumatic stress disorder among former Islamic State child soldiers in northern Iraq. The British Journal of Psychiatry, 213(1), 425-429.

11 Benotman, N., \& Malik, N. (2016). The Children of Islamic State. Quilliam Foundation, 7.

12 Thomason, K. K. (2016). Guilt and child soldiers. Ethical theory and moral practice, 19(1), 115-127.
} 
peers. Mothers in the camps complain that there are no toys but the rocks that children pick up and play with. Regardless of their exact experiences, all of the repatriated ISIS children will require support ranging from religious reeducation to psychological counseling to support to understand and reenter normal society.

The aforementioned challenges in dealing with the psychosocial impacts of being raised under ISIS can perhaps be informed by the Disarmament, Demobilization, and Reintegration [DDR] programs implemented with child soldiers in Africa and elsewhere. These programs involve psychosocial support, education, healthcare, and vocational training, and there are recent pushes to approach all of these aspects with a gendered perspective. There are also pushes to expand the program to include Rehabilitation - "DDR(R)." ${ }^{13}$ Criticisms of DDR programs typically lie in the institutional and structural inadequacies impeding proper implementation, including eligibility rules such as possession of a weapon that prevented many from participating. Therefore, DDR programs may be especially effective among repatriated ISIS children in countries with stronger and more well-established child welfare systems. Another potential improvement to the efficacy of DDR with ISIS children is the lower risk of re-recruitment if the children are taken back to their home countries and out of the environment in which they acted as child soldiers. ${ }^{14}$ This is particularly important as the first author has interviewed defected Iraqi and Syrian ISIS youth who were re-contacted by ISIS leaders trying to take them back into the group. Beyond DDR, some experts have recommended drawing from programs designed to help youth leave gangs. Like gang members, ISIS children have been taught a strict set of rules based on a twisted moral code and that their only protection lies within ISIS. They have been desensitized to violence and are at great risk for being rejected by their communities when they try to reintegrate. Therefore, countries with well-established programs for gang intervention may be able to build similarly effective programs for helping ISIS children. ${ }^{15}$

Harvard's Theresa Betancourt's longitudinal study of 260 child soldiers who took part in such programs in Sierra Leone points out that youth with accumulated risk factors, lack of protective factors, and persistent distress need to be identified with provisions for social supports and educational access made in order to rehabilitate them. She also recommends that psychosocial interventions for former child soldiers are likely to be more effective if they account for post-conflict factors such as stigma and community acceptance as well as war exposures, as a child that is actively rejected from society will fail to reintegrate well. Her study also demonstrated that success in school is central to rehabilitation, but that managing trauma-related mental health symptoms is necessary for a child to succeed in school. Thus education, trauma treatment and a wider systems approach involving the community in overcoming stigma and challenges to reintegration are all crucial for rehabilitation of child soldiers. The same is likely for child ISIS returnees.

Stevan Weine and Heidi Ellis of the University of Chicago recently developed the Rehabilitation and Reintegration Intervention Framework (RRIF) as an evidence-based model for working with child returnees. Their model is based on a review of 31 studies in the areas of refugee children, warimpacted children, child criminal gang members, child victims of maltreatment, and child victims of sex trafficking.

According to the authors, "The RRIF defines an approach that considers how five primary goals promoting individual mental health and well-being, promoting family support, promoting educational success, promoting community support, and improving structural conditions and protecting public safety - can be pursued across five levels of social interaction - individual, family, educational, community, and societal. Achieving these goals at all five levels requires cooperation between national and local governments, civil society, and scholars collaborating across disciplines." In many ways this model is very similar to other systems approaches to prevention and intervention of violent extremism. For example, the Aarhaus prevention model also brings a systems and community approach to dealing

13 Benotman, N., \& Malik, N. (2016). The Children of Islamic State. Quilliam Foundation, 7.

14 Mitra, A. (2019). Child Soldiers in the Democratic Republic of Congo: Revisiting 'Reintegration'through a Psycho-Social Framework. Allons-y: Journal of Children, Peace and Security, 3, 48-63.

15 Benotman, N., \& Malik, N. (2016). The Children of Islamic State. Quilliam Foundation, 7. 
with radicalized individuals.

Weine and Ellis argue that changing beliefs is less important than disengaging children from terrorism and that democracies allow for freedom of thoughts. While the latter is certainly true, the ICSVE stance is that given that ISIS put such emphasis and effort into forcing ideological training on its cadres and enforcing adherence it may be worth also addressing beliefs to truly rehabilitate those who were old enough to take on the ISIS ideology. Children that the first author has interviewed, have stated that it was very hard to shake ISIS's ideological training and adult interviewees have also said they could only deradicalize with ideological support from professionals that helped them to see that ISIS's version of Islam was a distorted and violent interpretation that most Islamic scholars do not support. The first author found the same, that Islamic challenge was useful in rehabilitation programs in Camp Bucca with al Qaeda prisoners who had been highly ideologically trained.

As with all aspects of repatriation and rehabilitation, it is crucial to keep a gender-based perspective. The experiences described previously apply far more to the boys living under ISIS, but girls were also indoctrinated into the ideology, witnessed overwhelming traumas of executions, violence and bombardments and were also taught the ISIS credo of "hear and obey." Girls were required to cover their hair beginning in first grade. ISIS also considered it appropriate for girls to marry as young as nine, suggesting that many of the older girls in the camps have histories of sexual abuse by their forced husbands. ${ }^{16}$ Teenage ISIS girls have told the first author that they were essentially raped in marriage and one was very traumatized by her resulting pregnancy, saying she would never be able to love the child she was carrying. Both girls and boys will likely struggle with issues of identity as they get older in societies very different from the ISIS Caliphate and the camps. In some cases it may be necessary to change their names so they can leave the past behind them. Establishing new roles and positive senses of self will also be an important aspect of rehabilitation and reintegration.

\section{What are the Risks of Repatriation?}

Aside from potentially opening the door for their parents to return home, there is no way to know with absolute certainty that repatriated children will not pose a risk to their countries when they return or for those born in ISIS, are brought home for the first time. This is the case in any instance of releasing people from prison or involuntary commitment in a psychiatric hospital, yet countries, especially those in Western Europe, have long promoted a system of short sentences that focuses on rehabilitation. They are able to do so through the use of risk assessment screening tools and proper rehabilitation programs. The ISIS children have almost certainly been traumatized: They may have witnessed or even committed atrocities; they have experienced bombings and all of the other inherently traumatic aspects of living in a war zone. ${ }^{17}$ Studies have shown that growing up in a war zone can be a major contributing aspect to the decision of adolescents and young adults to join armed groups. ${ }^{18}$ These traumas will need to be addressed through psychological counseling and developmentally appropriate social support. Moreover, the children may also suffer from complicated grief following the death of one or both parents and or siblings. If the children are separated from their mothers or siblings as a requirement for being repatriated, they will also be likely to suffer grief similar to losing a close family member. Studies of early-onset persistent delinquent youth - those who have already exhibited criminal behavior - have shown that early loss and grief contribute to internalizing syndromes such as anxiety and depression in both boys and girls and to externalizing syndromes such as oppositional defiant behavior in boys. ${ }^{19}$ Many ISIS children do not have living fathers and those that do will likely

16 Benotman, N., \& Malik, N. (2016). The Children of Islamic State. Quilliam Foundation, 7.

17 Thabet, A. A., A. N. Ibraheem, R. Shivram, E. A. Winter, and P. Vostanis. "Parenting support and PTSD in children of a war zone." International Journal of Social Psychiatry 55, no. 3 (2009): 226-237.

${ }_{18}$ Brett, R., Specht, I., \& Grey, J. (2005). Young soldiers: Why they choose to fight. International Journal, 60(4), 1181.

19 Lansing, A. E., Plante, W. Y., Beck, A. N., \& Ellenberg, M. (2018). Loss and grief among persistently delinquent youth: The contribution of adversity indicators and psychopathy-spectrum traits to broadband internalizing and externalizing psychopathology. Journal of child \& adolescent trauma, 11(3), 375-389. 
not have them present in their lives as their fathers will likely be imprisoned for a long time. Thus, the risk of boys acting out after being repatriated is not insignificant, especially if such externalizing symptoms are combined with prior ideological indoctrination that provides them with a target for their anger that is acceptable within their worldview.

These risks are critical to acknowledge, but countries who repatriate their children quickly have an opportunity to treat at-risk children before they develop any major psychosocial or behavioral difficulties. Most of the children are young enough to be especially malleable when given the care and support they need. Even teenagers who have participated in ISIS's crimes are good candidates for rehabilitation programs due to their young age and impressionability, ironically, the same traits that ISIS exploited. It must be emphasized, however, that all of these risks are exacerbated the longer countries take to repatriate the children.

Several case studies have indicated the potential for successful repatriation of ISIS children. While the rehabilitation and reintegration programs implemented in Kazakhstan and Kosovo have not yet produced significant results, there have not been any major security consequences of repatriation in those countries. In Sweden, Beatrice Erikson, founder of Repatriate the Children, assisted Patricio Galvéz in the rescue of his seven orphaned grandchildren. According to Ms. Erikson, the children, who were initially found in an SDF camp in April of 2019, are thriving with long-term foster families, regularly seeing each other as well as their grandfather. Even these simple social supports in addition to good healthcare have led to vast developmental progress. Ms. Erikson says that the youngest child was one and a half years old when he was found, weighing less than three kilograms (6.61 pounds). Now, she says, the child has "started to talk and is running around playing as any other child. If you would see these children now, you wouldn't almost be able to recognize them." Ambassador Peter Galbraith also referenced a mother and child dyad he helped to return to Germany who are both doing well, with the child attending public school and the mother, having totally turned her back on ISIS, now well integrated back into German society. Both Ms. Erikson and Ambassador Galbraith shared these hopeful results with hundreds of online viewers at ICSVE's Zoom panel, "Can We Repatriate the ISIS Children?".

\section{What Will Happen If the Children Are Not Repatriated?}

The risks of leaving foreign children in the detention camps in northeast Syria are great. As previously noted, the SDF cannot hold women and children in the camps indefinitely, nor can they keep male FTFs in custody without a proper trial and conviction. Thus, while some countries prefer to maintain the status quo, it is clear that the status quo is unstable. Likewise, Turkey has already incurred into the region and currently threatens the very existence of the SDF. Assad's government who are known for rape and torture of prisoners also wants to regain control of the region and may demand custody of the ISIS FTFs.

If the children are not repatriated, they will not simply continue living as they have in the camps. The most immediate danger is that the children will become sick and die. Disease spreads rapidly in the overcrowded camps, where many children are malnourished and do not have access to adequate healthcare. Mothers are wary about vaccinating their children due to questions about the quality of the vaccinations. Likewise there may also be a fear likely linked not to unfounded conspiracy theories, but to the fact that in 2011 the CIA organized a vaccination campaign in Pakistan in order to obtain DNA samples that would lead to the capture or killing of Osama bin Laden.

The SDF camps also exist in an unprecedented time with regard to disease. The spread of COVID-19 has killed hundreds of thousands of people in the Western world, and although many fatalities have not yet been reported from the camps, the circumstances there make the risk of mass contagion high. Even before the onset of COVID-19, one woman ominously expressed her fear of contagious disease to the first author: "There are a lot of sick people and [my children] are mixing with sick children. Once there was Typhoid; women and children died of this, vomiting blood. They don't give us masks. I said 
we need masks." Hoda Muthana expressed a similar fear for her toddler son, saying, "He has chronic bronchitis, he's always getting sick from the cold, he is always getting chest infections and that's what the kids die from here."

The children are also at risk in the camps, particularly in Camp Al-Hol, from the women who remain loyal to ISIS. As noted above, children of disillusioned mothers may have their tents burned down, witness their mothers beaten or even killed, and be harassed and assaulted themselves by the ISIS women and their children. Children of the women loyal to ISIS are vulnerable to even further radicalization than they may have received while living under the Caliphate. If their fathers are imprisoned, the children are taught that their fathers are being tortured and oppressed by unbelievers; the same people who guard the camps. Those guards are then used as targets by children honing their skills as jihadists. Many of the children have mothers who are widowed. While the disillusioned mothers may teach their children that ISIS either killed their fathers or cynically sent them to die, children of ISIS enforcers are taught that their fathers are "martyrs". The value of revenge and the distorted concept of Islamic martyrdom through suicide terrorism will be passed to these children, continuing the cycle of violence wherein the children will likely grow up to be jihadists intent on attacking the people and countries they hold responsible for their fathers' deaths.

Indeed, we have witnessed this phenomenon already. Some local Iraqi ISIS members interviewed by the first author had fathers, older brothers, and cousins who fought with al Qaeda in Iraq and were either killed or imprisoned by the U.S.-led coalition. While some were radicalized into the ideology of ISIS's precursor by this experience, the lack of opportunity experienced by Sunni Iraqis after the U.S. invasion was also a major contributing factor to their joining ISIS. In the International Center for the Study of Violent Extremism [ICSVE]'s study of 220 ISIS defectors, returnees, and imprisoned cadres, FTFs were significantly more motivated to join ISIS by ideological factors like the dream of building a Caliphate and the obligation to fight jihad than were Iraqi and Syrian ISIS members. By contrast the local Iraqi and Syrian ISIS members were motivated to join more by needs for food, money, employment, and family security. The children and their mothers remaining in the camps, as well as the male FTFs, are now essentially all locals. If ISIS is able to regain control in the area, they are apt to rejoin the group out of desperation just as many locals previously did, even if they no longer ascribe to the ideology.

Syrian ISIS defector Abu Musab described to the first author the combination of desperation and anger that pushed him to join ISIS, exemplifying the reasons why children left in the camps are at risk for joining ISIS or other violent extremist groups in the future: "Before ISIS, and the revolution, I was at school. Then the revolution took place. For some time, my father was outside [the home]. Then the regime bombed the area and my father died as a 'martyr' in that bombing. I became the provider for my family." He describes being asked by his teacher to declare his loyalty as a Cub of the Caliphate. Abu Musab explains his motivations clearly, describing how both basic needs and a desire for revenge influenced his decision to join: "My father had been killed as a 'martyr' under the regime [...] The offers were very appealing. I was the only provider and life had become very difficult."

The risk of ISIS regaining control is also connected to the Turkish incursions in the area. When President Trump withdrew U.S. troops from northeast Syria in October of 2019, he greenlit Turkish President Erdogan to attack. SDF troops previously guarding the camps and prisons were pulled away from their posts to fight the Turkish invaders, leaving security gaps and allowing for escapes. When Turkey bombed the area, Camp Ain Issa was hit, sending women and children running for their lives. The SDF says that all of the male FTFs were recaptured, but many of the women were able to make it out of Syria. Irishwoman Lisa Smith, for instance, escaped to Turkey and was repatriated to Ireland, where she is now living in her community on bail with her daughter. Other ISIS women wait upon the ISIS men, some of whom are now fighting as Turkish-backed rebels to come and free them from the camps. In the future, if the SDF is not able to prosecute and successfully convict the FTFs, the FTFs will be placed in even more horrific situations if they are not repatriated. French FTFs have already been tried and sentenced in Iraq, where the justice system does not grant defendants the same rights that they 
would be granted in their home countries, such as the right to a fair trial and the right to be tried by a jury of one's peers. Iraq has imposed harsh and prolonged sentences for ISIS membership, even on minors who attended ISIS training camps for only a few weeks, and on women, many of whom, were imprisoned in their homes throughout their time in ISIS. If FTFs are tried and imprisoned by the Syrian Assad regime, which is still the official government of Syria, they will likely be subject to sham trials, forced confessions, torture, and rape. Surely, a child whose parent undergoes such atrocities at the hands of the Iraqi or Syrian government because their own country refused to repatriate them will be ripe for radicalization and eager to seek revenge on said country.

\section{What Are the Next Steps for Repatriation?}

In Western Europe, the repatriation of children has been viewed through a humanitarian lens but has largely been stymied by the refusal to repatriate adult FTFs, thus allowing only orphans and other unaccompanied children to be repatriated and leaving the majority of the children in the camps. Anthony Dworkin argues that a case must be made for repatriation of FTFs and their families in order for repatriation to occur in a successful and systematic manner. This campaign must be aimed at swaying public opinion so that governments do not feel political pressure not to repatriate. According to Dworkin, a campaign for repatriation does not need to be based solely on humanitarian grounds, but from a security perspective as well: Repatriation allows countries to keep track of their FTFs, who could make it home secretly either by escaping as the women did after the Turkish destruction of Camp Ain Issa, by paying to be smuggled out, as is happening frequently in Camp Al-Hol, or by being broken out by ISIS fighters.

Dr. Christophe Paulussen agrees that the issue of repatriation can be advocated from both moral and security standpoints but goes further to argue that FTFs' countries owe it to the SDF to take their people back. The FTFs were largely radicalized in their home countries but mostly did not attack at home. When they were leaving their countries, many security and intelligence services were aware but glad to see them exit. One Belgian police officer referred to the exit of jihadist from his country as Belgium "flushing the toilet." Likewise, while most transited through Turkey legally, they entered Syria illegally. It was the SDF who fought the FTFs on the frontlines, who suffered the most casualties in the fight against ISIS, far more than the countries from whence the ISIS fighters came. Now, these same countries are failing to take responsibility for their own citizens' actions, leaving the SDF to continue to shoulder the burden on their own. Dr. Paulussen also cites former Dutch Minister of Foreign Affairs Bert Koenders, who explained the hypocrisy of leaving FTFs in Syria: "We keep referring to these people as foreign terrorist fighters. The uncomfortable truth is that they are not foreign at all. They may be foreigners in the countries where they are going to. But in reality, they are our compatriots, our acquaintances, the classmates of our kids, the guys and girls we see in our supermarkets. They are part of our societies. Perhaps the only thing that's foreign to us is their mentality."

The only aspect preventing these countries from adopting a policy of repatriation, attests Dr. Paulussen, is "a lack of political will [...] The prosecutors are ready to prosecute; the child care specialists are ready to treat the children; from an international legal aspect, experts say this is the best thing to do [...] it's only the politicians who are lagging behind." Indeed, ICSVE has been working with many countries, most frequently Germany, in assisting federal prosecutors to be ready to prosecute their ISIS members held in northeast Syria by providing the justice ministries, with the detainees' full permission, the notes of in-depth interviews done with them as well as viewing together our video recording of the interviews and consulting about their cases. Such an approach, according to German justice authorities, is vastly helpful to construct a strong case for successful prosecution which makes it more likely that politicians can agree to repatriate ISIS members.

The evidence presented in this article clearly demonstrates the necessity of repatriating ISIS children in a systematic way, not based only on the public's perception of the specific child or mother. Repatriation of the children in the SDF camps is, from a security perspective, the best way to prevent 
these children from becoming the next generation of militant jihadists. From a legal perspective, states are neglecting, if not maltreating, children by leaving them in dire conditions at risk for abuse, disease, and bombardments. From a moral and humanitarian perspective, failure to repatriate these children is a violation of their fundamental rights to be protected and cared for. The experts agree, but fear on a political level appears to take precedence. 